\title{
Evidence of Burmese Pythons, Python bivittatus (Kuhl 1820) (Pythonidae), in the Shivalik Forest Division, India
}

\author{
Devavrat Pawar ${ }^{1}$, Siddhant Umariya ${ }^{1}$, V.K. Jain ${ }^{2}$, A.K. Singh ${ }^{1}$, and I.P. Bopanna ${ }^{1}$ \\ ${ }^{1}$ WWF-India, Rajpur Road, Dehradun, Uttarakhand-248001, India (dpawar@wwfindia.net) \\ ${ }^{2}$ Office of Conservator of Forests, 2/2419, Court Road, Gill Colony, Saharanpur, Uttar Pradesh-247001, India
}

$\mathrm{T}$ he Burmese Python (Python bivittatus) is one of the largest snakes in the world (Penning et al. 2015). Little is known about its status and distribution in India, largely because the Burmese Python until recently (Jacobs et al. 2009) was considered a subspecies of the Indian Rock Python (Python molurus) (e.g., Whitaker and Captain 2004), with which it is frequently confused - especially in the Terai Region (lowlands in the foothills of the Himalayas). However, recent observations suggest that almost all the records of pythons in the Terai Belt actually represent Burmese Pythons.

The two species are difficult to differentiate morphologically. Coloration of the Indian Rock Python is more yellowish and the sixth or seventh supralabial is in contact with the eye, whereas the Burmese Python is lighter with dark brown, blackbordered blotches and the sixth supralabial is separated from the eye by a subocular scale (Whitaker and Captain 2004).

Burmese Pythons thrive in marshes and swamps, exemplified by the rapid increase in the introduced population in Florida, USA (e.g., Nafus et al. 2020). However, forested areas, including mangroves and rainforests, grasslands, coastal plains, and rocky foothills also provide suitable habitat (e.g., O'Shea 1998; Barker and Barker 2008). In India, the Burmese Python is protected under the Indian Wildlife (Protection) Act, 1972 and is listed under schedule 1 which provides the species the highest level of protection. It is listed as Vulnerable (VU) on the IUCN Red List (Stuart et al. 2012) and is included in CITES Appendix II (CITES 2019).

Previous records of Burmese Pythons in the Terai Region from inside and outside protected areas include the Hastinapur Wildlife Sanctuary in Meerut, Uttar Pradesh (Yadav et al. 2017), Rajaji Tiger Reserve and Timli Forest Range in Uttarakhand (Joshi and Singh 2015), and Amangarh Tiger Reserve, Uttar Pradesh (Hushangabadkar et al. 2019). Herein we provide photographic evidence of a range exten- sion of the Burmese Python in the Shivalik Forest Division, which could be the westernmost record of the species in India.

The snake (Fig. 1) was captured on a camera trap, deployed for the purpose of monitoring and recording the fauna found in the Shivalik Forest Division under a joint project between WWF-India and the Shivalik Forest Division of Uttar Pradesh, on 20 February 2020 in the Barkala Range of Shivalik Forest Division $\left(30.39459^{\circ} \mathrm{N}, 77.62455^{\circ} \mathrm{E}\right.$; elev. $548 \mathrm{~m}$ asl). Habitat at the site where the snake was photographed consisted of moist deciduous mixed forest (Fig. 2).

Anecdotal information suggests that sightings of Burmese Pythons in the region are rare. Populations of the species throughout its range are experiencing rapid declines due to deforestation for unplanned development, poaching, and fires set by humans to burn agricultural residue (Stuart et al. 2012). Additional surveys and intensive studies of the species' ecology are necessary to better understand the status and distribution of Burmese Pythons in India's Terai Region and to develop management strategies for its long-term conservation.

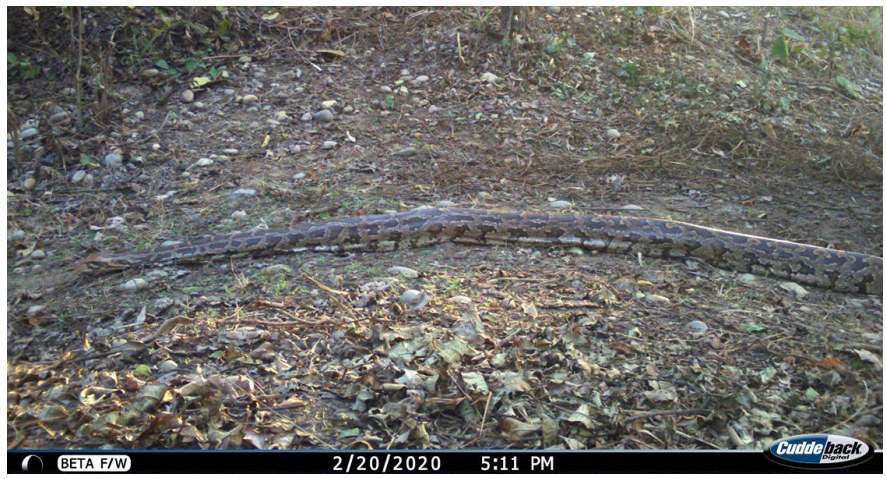

Fig. 1. Image of a female Burmese Python (Python bivittatus) captured by a camera trap in the Barkala Range, Shivalik Forest Division, Uttar Pradesh, India. Photograph courtesy of WWF-India, Shivalik Forest Department. 


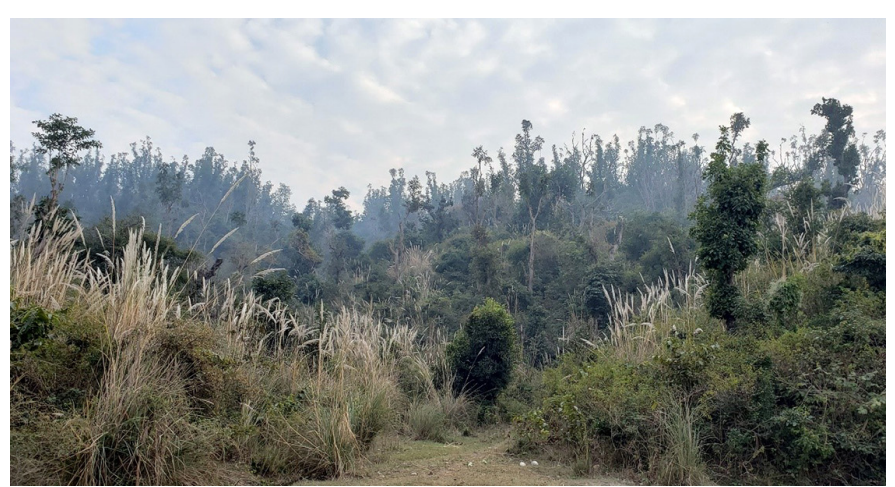

Fig. 2. Habitat where an image of a Burmese Python (Python bivittatus) was captured by a camera trap in the Barkala Range, Shivalik Forest Division, Uttar Pradesh, India. Photograph by Siddhant Umariya.

\section{Acknowledgements}

We thank Mr. Ravi Singh, SG \& CEO, WWF-India; Dr. Sejal Worah; Dr. Dipankar Ghose; and Mr. Yash Magan Sethia for providing organizational resources. We also thank Mr. Anuj Kumar for providing the image of the Burmese Python and Dr Abhijit Das, Scientist at WII, for confirming the identity of the species. The Forest staff of Shivalik Forest Division, Uttar Pradesh, lent support and issued the permit allowing us to conduct surveys. Special thanks go to WWF India's field assistants, interns, and support staff in the Shivalik Forest Division for their help in difficult field conditions.

\section{Literature Cited}

Barker, D.G. and T.M. Barker. 2008. The distribution of the Burmese Python, Python molurus bivittatus. Bulletin of the Chicago Herpetological Society 43: 33-38.

CITES (Convention on International Trade in Endangered Species of Wild Fauna and Flora). 2019. Appendices. <https://www.cites.org/eng/app/appendices.php>.

Hushangabadkar, P., M. Anwar, and S. Shafi. 2019. Distribution record of Python bivittatus in Amangarh Tiger Reserve, Uttar Pradesh, India. Reptile Rap\#194. In: Zoo's Print Journal 34(5): 20-22.

Jacobs, H.J., M. Auliya, and W. Böhme. 2009. Zur Taxonomie des dunklen Tigerpythons, Python molurus bivittatus Kuhl, 1820, speziell der Population von Sulawesi. Sauria 31(3): 5-16.

Joshi, R. and A. Singh. 2015. Range extension and geographic distribution records for the Burmese Python, Python bivittatus Kuhl, 1820 (Reptilia: Pythonidae) in northwestern India. Reptiles \& Amphibians 22: 102-105.

Nafus, M.G., F.J. Mazzotti, and R.N. Reed. 2020.Estimating detection probability for Burmese Pythons with few detections and zero recaptures. Journal of Herpetology 54: 24-30.

O'Shea, M. 1998. Herpetological results of two short field excursions to the Royal Bardia region of western Nepal, including range extensions for Assamese/IndoChinese snake taxa, pp. 306-317. In: A. de Silva (ed.), Biology and Conservation of the Amphibians, Reptiles, and their Habitats in South Asia. Proceedings of the International Conference on Biology and Conservation of Amphibians and Reptiles in South Asia, Sri Lanka, August 1-5, 1996. Amphibia and Reptile Research Organization of Sri Lanka (ARROS), Peradeniya, Sri Lanka.

Penning, D.A., S.F. Dartez, and B.R. Moon. 2015. The big squeeze: scaling of constriction pressure in two of the world's largest snakes, Python reticulatus and Python molurus bivittatus. Journal of Experimental Biology 218: 3364-3367.

Stuart, B., T.Q. Nguyen, N. Thy, L. Grismer, T. Chan-Ard, D. Iskandar, E. Golynsky, and M.W.N. Lau. 2012. Python bivittatus (errata version published in 2019). The IUCN Red List of Threatened Species 2012: e.T193451A151341916.

Whitaker, R. and A. Captain. 2004. Snakes of India. The Field Guide. Draco Books, Chennai, India.

Yadav, S.K., A. Khan, and M.S. Khan. 2017. Burmese Python. Python bivittatus: An addition to the reptiles of Hastinapur Wildlife Sanctuary, Uttar Pradesh, India. Reptile Rap\#175. In: Zoo's Print Journal 32(8): 25-29. 